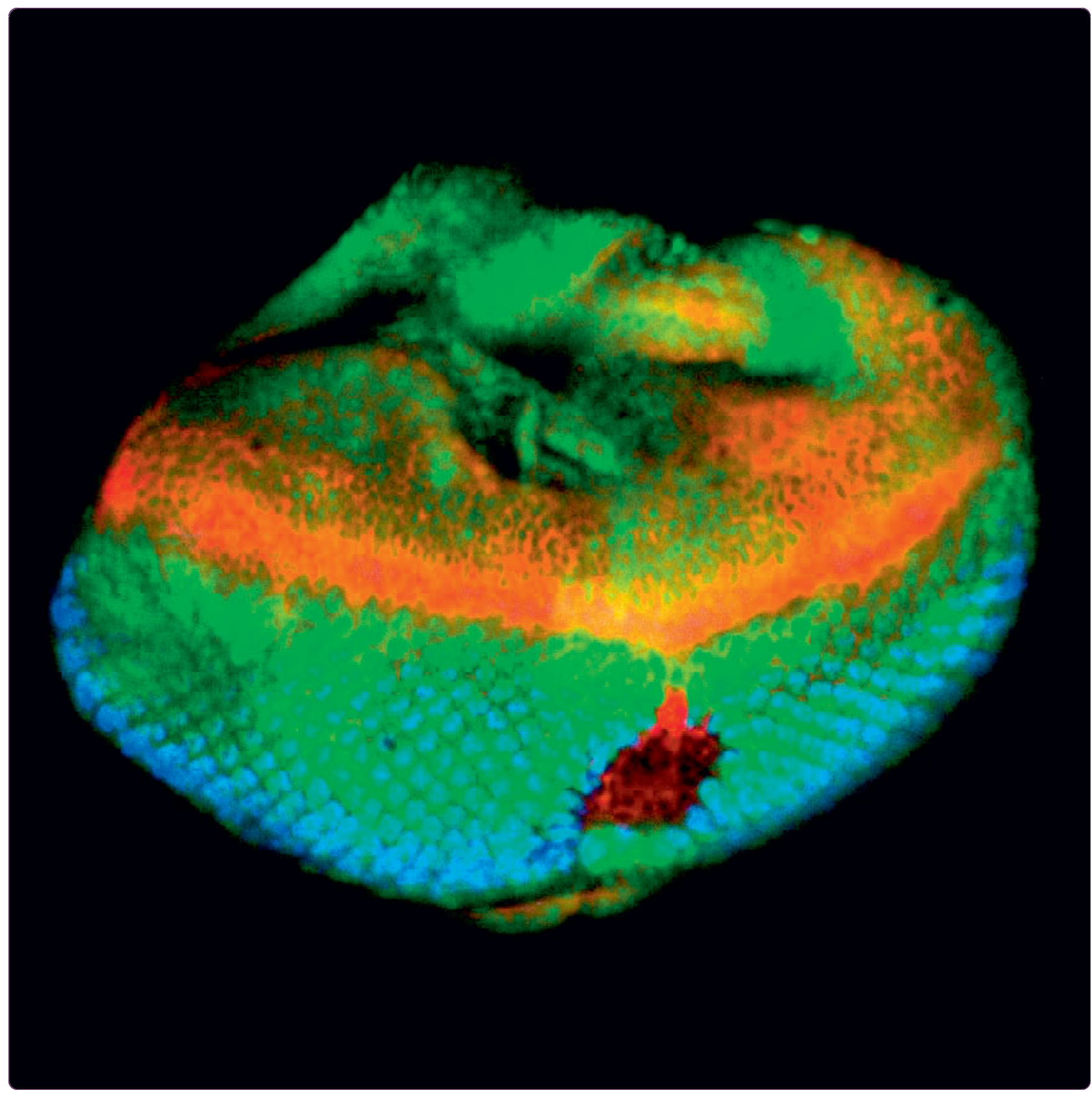

\title{
Ihog and Boi are essential for Hedgehog signaling in Drosophila
}

Camp et al. 


\title{
Ihog and Boi are essential for Hedgehog signaling in Drosophila
}

\author{
Darius Camp ${ }^{1,2,3}$, Ko Currie ${ }^{2}$, Alain Labbé ${ }^{2}$, Donald J van Meyel ${ }^{2,4,5^{*}}$, Frédéric Charron ${ }^{1,3,5,6,7,8^{*}}$
}

\begin{abstract}
Background: The Hedgehog (Hh) signaling pathway is important for the development of a variety of tissues in both vertebrates and invertebrates. For example, in developing nervous systems Hh signaling is required for the normal differentiation of neural progenitors into mature neurons. The molecular signaling mechanism underlying the function of Hh is not fully understood. In Drosophila, Ihog (Interference hedgehog) and Boi (Brother of Ihog) are related transmembrane proteins of the immunoglobulin superfamily (IgSF) with orthologs in vertebrates. Members of this IgSF subfamily have been shown to bind $\mathrm{Hh}$ and promote pathway activation but their exact role in the $\mathrm{Hh}$ signaling pathway has remained elusive. To better understand this role in vivo, we generated loss-of-function mutations of the ihog and boi genes, and investigated their effects in developing eye and wing imaginal discs.

Results: While mutation of either ihog or boi alone had no discernible effect on imaginal tissues, cells in the developing eye disc that were mutant for both ihog and boi failed to activate the Hh pathway, causing severe disruption of photoreceptor differentiation in the retina. In the anterior compartment of the developing wing disc, where different concentrations of the Hh morphogen elicit distinct cellular responses, cells mutant for both ihog and boi failed to activate responses at either high or low thresholds of Hh signaling. They also lost their affinity for neighboring cells and aberrantly sorted out from the anterior compartment of the wing disc into posterior territory. We found that ihog and boi are required for the accumulation of the essential Hh signaling mediator Smoothened (Smo) in Hh-responsive cells, providing evidence that Ihog and Boi act upstream of Smo in the Hh signaling pathway.

Conclusions: The consequences of boi;ihog mutations for eye development, neural differentiation and wing patterning phenocopy those of smo mutations and uncover an essential role for Ihog and Boi in the Hh signaling pathway.
\end{abstract}

\section{Background}

The Hedgehog (Hh) signaling pathway is essential for proper embryonic development, and aberrant Hh pathway activity is the cause of several human congenital defects and cancers [1-3]. In developing nervous systems, Hh is an important factor governing neural fate specification, neural precursor proliferation, and axon guidance [3-5]. For example, Hh signaling specifies neural cell fate identity in the developing neural tube of vertebrates [4], and is essential for the normal differentiation of photoreceptors in the Drosophila compound

\footnotetext{
*Correspondence: don.vanmeyel@mcgill.ca; Frederic.Charron@ircm.qc.ca 'Molecular Biology of Neural Development, Institut de Recherches Cliniques de Montréal (IRCM), Montreal, QC, H2W 1R7, Canada

${ }^{2}$ Centre for Research in Neuroscience and the McGill University Health

Centre Research Institute, 1650 Cedar Ave, Montreal, QC, H3G 1A4, Canada Full list of author information is available at the end of the article
}

eye [6]. Despite its importance in these and many other developmental events in diverse species, the molecular signaling mechanism underlying the function of $\mathrm{Hh}$ is still not fully elucidated.

$\mathrm{Hh}$ is a secreted protein that elicits concentrationdependent effects [3,4]. Genetic and biochemical experiments have led to a model where Patched (Ptc), a 12-pass transmembrane protein, is involved in sensing the extracellular Hh concentration [2]. In the absence of Hh, Ptc maintains the 7-pass transmembrane protein Smoothened (Smo) in a repressed state. Under these conditions, the Cubitus interruptus $(\mathrm{Ci})$ transcription factor is proteolytically cleaved and acts as a transcriptional repressor. Conversely, in the presence of Hh, Ptc-mediated repression of Smo is relieved and this leads to the stabilization
C Biomed Central 
of full-length $\mathrm{Ci}$ (Ci155), which activates transcription of Hh target genes.

Ihog (Interference hedgehog; CG9211) and Boi (Brother of Ihog; CG13756) are two related immunoglobulin superfamily (IgSF) members composed of four immunoglobulin-like (Ig) domains, two fibronectin type III (FN3) repeats, a transmembrane domain, and a cytoplasmic tail [7-9]. The first FN3 domain of Ihog is required and sufficient for direct binding to $\mathrm{Hh}[9,10]$. In transcription reporter assays in cultured cells, modulation of Ihog and Boi levels affected the strength of responses to Hh $[8,9]$. Although Ptc plays a critical role in sensing the Hh morphogenic gradient, the identification of Ihog and Boi as proteins that bind to $\mathrm{Hh}$ and promote pathway activation raised questions about their exact role in the Hh signaling pathway. To better understand this role in vivo, we generated loss-of-function mutations of the ihog and boi genes in Drosophila. We have investigated the effects of these mutations in developing eye and wing imaginal discs, and found that Ihog and Boi are functionally redundant and are required for Hh signaling in these tissues. This work uncovers an essential role for Ihog and Boi in the Hh signaling pathway.

\section{Results}

\section{Generation of ihog and boi mutants in Drosophila}

We generated an ihog null mutant $\left(i h o g^{D C 1}\right.$ ) that completely lacks the ihog coding sequence plus a portion of the 5' untranslated region of the adjacent gene CG10158 (Figure 1A; see Materials and methods). The absence of ihog mRNA transcripts in $i h o g^{D C 1 / D C 1}$ mutants was confirmed by in situ hybridization (Figure 1F) and by reverse transcriptase PCR (RT-PCR; Figure 2D). ihog ${ }^{D C 1 / D C 1}$ homozygotes or ihog ${ }^{D C 1 / D f}$ hemizygotes were viable and fertile (Table 1). However, we observed semi-lethality when mutant progeny (ihog ${ }^{D C 1 / D C 1}$ or ihog ${ }^{D C 1 / D f}$ ) but not heterozygous progeny $\left(i h o g^{D C 1 /+}\right.$ ) were derived from ihog ${ }^{D C 1 / D C 1}$ homozygous mothers (Table 1).

We characterized a UAS-ihog:myc transgenic line with basal levels of expression in the absence of a Gal4 driver (Figure 2D). Eclosion and adult viability were fully rescued in the presence of UAS-ihog::myc (Table 1), demonstrating that death at pupal stages was caused by loss of Ihog function and not CG10158. Together, the data indicate that zygotic Ihog is important for adult viability only in the absence of maternal Ihog.

The viability and lack of overt Hh-like phenotypes in ihog ${ }^{D C 1}$ mutants prompted us to also investigate Boi, since it behaves similarly to Ihog in Hh transcription reporter assays in vitro [9]. We used chemical mutagenesis to generate a boi mutation $\left(b o i^{C 1}\right)$ in a genetic screen (Figure 1B; Additional file 1; see Materials and methods). $b o i^{C 1}$ causes a premature stop codon at amino acid Trp626 (Figure 1B). This mutation is predicted to truncate the Boi protein within the second FN3 domain, and fails to encode the transmembrane domain and cytoplasmic tail (Figure 1C). Therefore, the $b o i^{C 1}$ mutation is predicted to severely disrupt the properties of Boi. The boi gene is situated on the X chromosome and therefore males are $b o i^{C 1 /-}$ hemizygotes. Similar to ihog, $b o i^{C 1 / C 1}$ female flies and $b o i^{C 1 /-}$ male flies were viable and fertile, but unlike ihog there was no maternal effect.

Thus, zygotic mutants for either $i h o g^{D C 1}$ or $b o i^{C 1}$ were viable and exhibited no overt phenotype reminiscent of mutations of components of the Hh signaling pathway. However, larvae that were double mutants for $i h o g^{D C 1}$ and $b o i^{C 1}$ died 24 to 48 hours after hatching, and never reached third instar (L3), suggesting that ihog and boi might act redundantly. In support of this idea, viability of double mutants was rescued in the presence of UASihog::myc, suggesting that Ihog could supplant Boi function in these flies (Figure 2C).

\section{Effects of ihog and boi mutations in the developing visual system}

In the developing Drosophila retina, neuronal differentiation within the eye imaginal disc proceeds stepwise in the wake of a constriction in the disc epithelium called the morphogenetic furrow (MF) [11]. Hh signaling is required for the initiation of the MF at the posterior margin of the disc, and for its wave-like progression across the disc that marks the boundary between undifferentiated anterior cells and differentiating posterior cells [6]. Previous studies have demonstrated that clones of cells in the developing eye disc that lack the essential Hh mediator Smo retard MF progression and exhibit a cell-autonomous delay of differentiation into photoreceptors (R-cells) [12,13].

To begin to investigate whether ihog and boi could play a role in the developing visual system, we studied their expression in wild-type L3 larvae using in situ hybridization (Figure 1D, E). Transcripts for both genes were observed throughout the developing eye disc, but were enriched in anterior regions characterized by undifferentiated cells compared to the posterior regions where there is ongoing differentiation of retinal cell types. Transcripts for neither ihog nor boi were detected in the optic lobe and other regions of the brain at this stage. We confirmed the complete loss of ihog mRNA in ihog ${ }^{D C 1}$ mutants (Figure 1F) and thereby demonstrated the specificity of the ihog probe. We could not do likewise with the boi probe, since it was predicted to hybridize with transcripts from the $b o i^{C 1}$ nonsense mutation. However, the boi probe is unlikely to cross-hybridize with $i h o g$ transcripts as the $i h o g$ probe does not detect boi transcripts in ihog ${ }^{D C 1 / D C 1}$ mutants. Together, these 


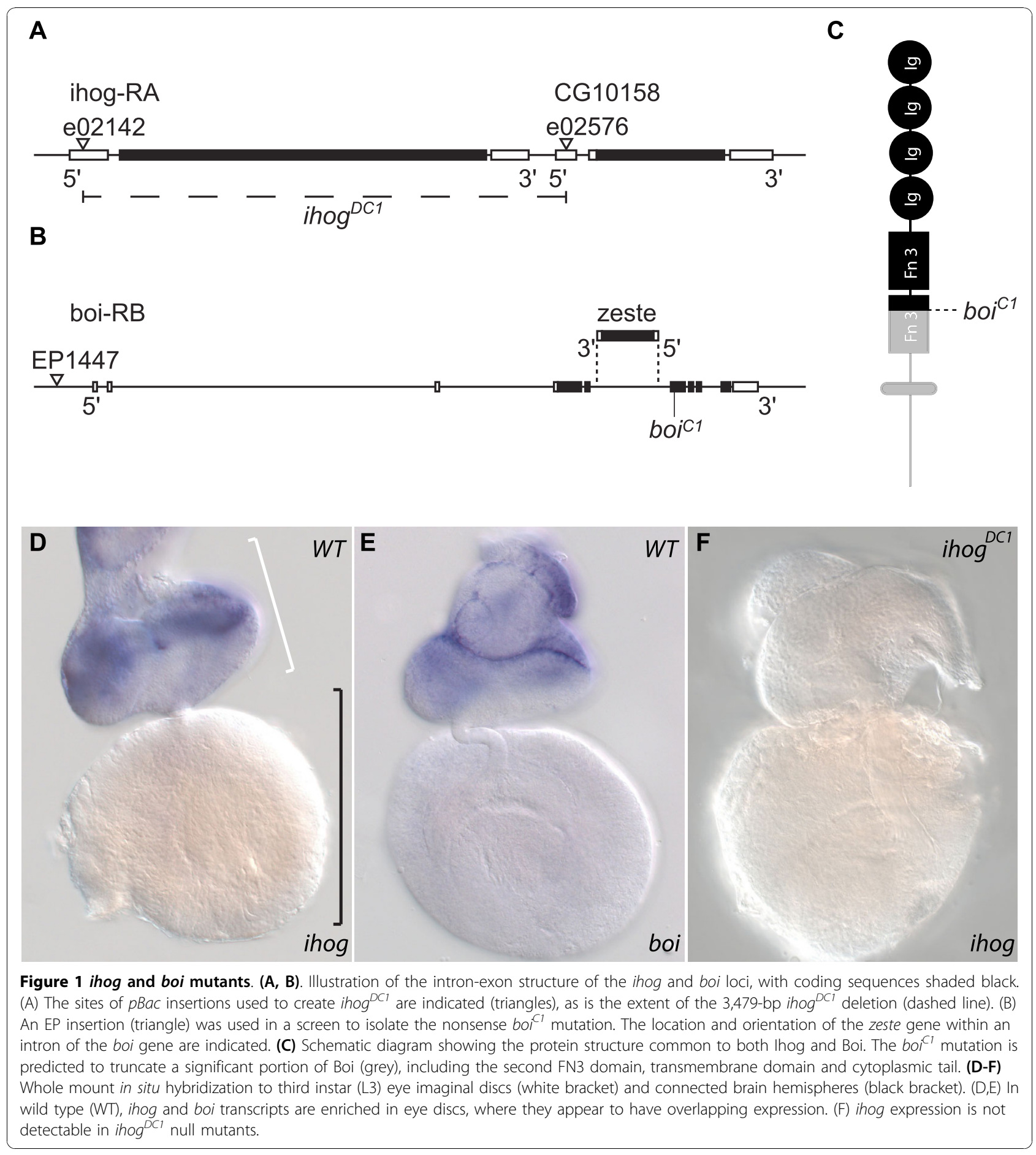

data revealed overlapping expression of ihog and boi in the developing eye disc, supporting the idea that they might act redundantly in this context.

To test this directly, we needed to generate mosaic animals because, as noted above, double mutant larvae died prior to L3. In $b o i^{C 1 /-}$ hemizygotes, we used FLP-mediated mitotic recombination to render the majority of cells in the developing eye discs also mutant for $i h o g^{D C 1 / D C 1}$ [14]. Eye development was severely compromised in these mosaic animals (Figure 2B), leading to structural defects reminiscent of those found in smo and hh mosaics [15-17]. Control mosaics in which ihog ${ }^{D C 1 / D C 1}$ eye discs were generated in $b o i^{C l /+}$ heterozygotes had normal eyes (Figure 2A). Additional controls with normal eyes were $b o i^{C 1 /}$; 

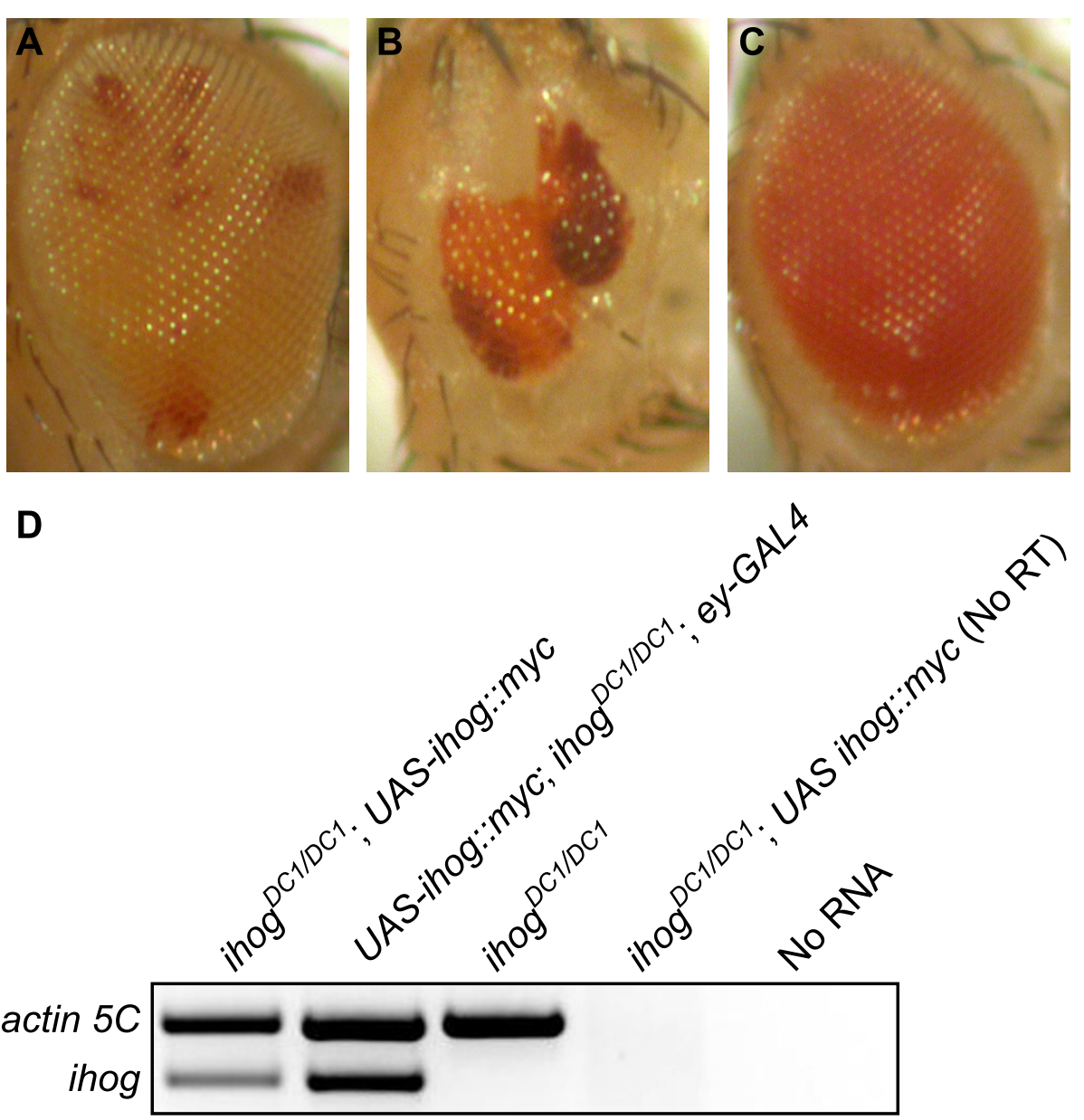

Figure 2 Double mutations of ihog and boi severely disrupt eye development. (A) Normal morphology of an ihog ${ }^{D C 1}$ mosaic eye in a boi $i^{C 1 /+}$ heterozygote (genotype: boi ${ }^{C 1} /+$; ihog ${ }^{D C 1}$, FRT40A/FRT4OA, I(2)CL-L1; ey-FLP/+). Ommatidia composed of ihog ${ }^{D C 1 / D C 1}$ homozygous cells are pigmented orange, while the dark red patches mark ommatidia with ihog ${ }^{D C 1 /+}$ heterozygous cells. (B) Eye morphology is severely disrupted in an ihog ${ }^{D C 1}$ mosaic eye in a boi ${ }^{C 1 /}$ mutant (genotype: boi ${ }^{C 1} / Y_{\text {; }}$ ihog ${ }^{D C 1}$, FRT4OA/FRT4OA, I(2)CL-L1; ey-FLP/+). The eye is small, poorly shaped, and many ommatidia are missing. Some double mutant ommatidia appear to differentiate in these mosaics but have a roughened appearance, which is consistent with smo mutations. (C) Addition of Ihog rescues viability and eye morphology in a double mutant (genotype: boi ${ }^{11} / Y_{\text {; }}$ ihog ${ }^{D C 1 / D C 1}$; UAS-ihog::myC/+). (D) RT-PCR to demonstrate loss of ihog transcripts in ihog ${ }^{D C 1 / D C 1}$ mutants, and to characterize a transgenic line with low-level, constitutive expression of UAS-ihog::myc in the absence of a Gal4 driver.

ihog $g^{D C 1 /+}$ males (not shown) and rescued double mutants (genotype: $b o i^{C 1 /}$; ihog $^{D C 1 / D C 1}$; UAS-ihog::myc/+; Figure 2C). These results indicated that Ihog and Boi are together required for the proper development of the Drosophila eye.

\section{Ihog and Boi are required for Hh signaling and neuronal differentiation in the eye imaginal disc}

To determine whether the disruption of eye development that we observed was due to perturbation of the Hh signaling pathway, we first examined the distribution of Ci155, a Gli-related zinc-finger protein that regulates transcription of Hh-responsive genes. Hh signaling inhibits proteolytic processing of Ci155 to the truncated repressor form Ci75 [3,18]. Using an antibody that detects Ci155 but not $\mathrm{Ci75}$, one can monitor Hh signaling in cells that accumulate high levels of Ci155 [19]. In eye discs of L3 larvae, Ci155 normally accumulates to high levels just anterior to the advancing MF, marking Hh signaling that is required for MF progression [12,20,21]. In control experiments, we generated $i h o g^{D C 1 / D C 1}$ clones in $b o i^{C 1 /+}$ heterozygotes and found no effect on Ci155 accumulation just anterior to the MF (eight of eight clones; Figure 3AB"). In contrast, ihog ${ }^{D C 1 / D C 1}$ clones in $b o i^{C 1 /-}$ mutants had no detectable Ci155 expression at the MF (11 of 11 clones; Figure 3C-D"), indicating a loss of Hh signal transduction in double mutant cells.

Like smo mutant clones $[12,15]$, we found that boi;ihog double mutant clones failed to express Elav, a neuronspecific marker for R-cells in the eye disc (green fluorescent protein (GFP)-negative in Figure 3E-E”). In 
Table 1 Effect of ihog mutation on adult viability

\begin{tabular}{|c|c|c|}
\hline & Expected & Observed \\
\hline \multicolumn{3}{|c|}{ Cross: ihog ${ }^{D C 1 /+}$ females $(f) \times$ ihog ${ }^{D f /+}$ males $(m)$} \\
\hline \multicolumn{3}{|c|}{$\mathrm{F} 1(\mathrm{n}=208)$} \\
\hline$i h o g^{+/+}$ & $25 \%$ & $20 \%^{\mathrm{a}}$ \\
\hline ihog $^{D C 1 /+}$ & $25 \%$ & $21 \%^{\mathrm{a}}$ \\
\hline$i_{h o g}{ }^{D f /+}$ & $25 \%$ & $35 \%^{\mathrm{a}}$ \\
\hline ihog $^{D C 1 / D f}$ & $25 \%$ & $24 \%^{a}$ \\
\hline \multicolumn{3}{|l|}{ Cross: ihog $g^{D C 1 / D C 1}(\mathrm{f}) \times$ ihog $^{D f /+}(\mathrm{m})$} \\
\hline \multicolumn{3}{|l|}{$\mathrm{F} 1(\mathrm{n}=125)$} \\
\hline ihog $^{D C 1 /+}$ & $50 \%$ & $90 \%{ }^{b}$ \\
\hline$i_{h o g} D C 1 / D f$ & $50 \%$ & $10 \%{ }^{b}$ \\
\hline \multicolumn{3}{|l|}{$\begin{array}{l}\text { Cross: ihog }{ }^{D C 1 / D C 1}(\mathrm{f}) \times \text { ihog }^{D C 1 /+} \\
\text { 7UAS ihog: } \\
\text { myc/ }(\mathrm{m})\end{array}$} \\
\hline \multicolumn{3}{|l|}{$F 1(n=73)$} \\
\hline ihog ${ }^{D C 1 / D C 1}$; UAS ihog:: myc/+ & $25 \%$ & $29 \%^{\mathrm{b}}$ \\
\hline ihog $^{D C 1 / D C 1}$ & $25 \%$ & $5 \%^{\mathrm{b}}$ \\
\hline ihog ${ }^{D C 1 /+}$; UAS ihog::myc & $25 \%$ & $33 \%{ }^{b}$ \\
\hline$i_{h o g} D C 1 /+$ & $25 \%$ & $33 \%{ }^{b}$ \\
\hline
\end{tabular}

The observed segregation ratio is not statistically different from expected (chi-square test: $P>0.05$ ). ${ }^{\text {b}}$ The observed segregation ratio is statistically different from expected (chi-square test: $P<0.05$ ).

controls, cells posterior to the MF that were mutant for only ihog (GFP-negative in Figure 3A, B) or only boi (GFP-positive in Figure 3E) expressed Elav normally, indicating that simultaneous loss of both family members is required to affect $\mathrm{R}$-cell differentiation.

Elevated Ci155 levels drop sharply in cells posterior to the MF in a Cullin-3-dependent proteolytic process associated with the onset of R-cell differentiation $[12,15]$. As in the case of smo mutant clones $[12,15]$, the absence of R-cells in clones lacking ihog and boi is accompanied by ectopic accumulation of Ci155 in clones located posterior to the MF (Figure 3E-E"). Taken together, our data suggest that Ihog and Boi are functionally redundant and, like Smo, are essential for the differentiation of R-cells in response to $\mathrm{Hh}$.

\section{Ihog and Boi are required cell-autonomously for both high- and low-threshold responses to Hh pathway activation}

To determine whether Ihog and Boi also function in $\mathrm{Hh}$ signaling elsewhere, and to explore whether they mediate high-threshold and low-threshold responses to a $\mathrm{Hh}$ morphogen gradient in vivo, we examined their role in wing development. Subdivision of the developing imaginal wing disc into anterior and posterior compartments involves the posterior-specific expression of the selector gene Engrailed [22], which programs posterior cells to produce and secrete $\mathrm{Hh}$, and simultaneously prevents their response to $\mathrm{Hh}$ by blocking expression of $\mathrm{Ci}$
$[23,24]$. Therefore, only anterior cells limited to a broad stripe along the anterior/posterior compartment boundary can respond to $\mathrm{Hh}$, and they do so by upregulating the expression of Hh target genes in a manner that depends on their proximity to the boundary and therefore the concentration of Hh to which they are exposed [25]. Cells immediately adjacent to the compartment boundary respond to high levels of Hh by expressing Ptc, a direct transcriptional target of Hh signaling [26]. Cells positioned more anteriorly respond to lower levels of Hh marked by high Ci155 accumulation, though all anterior cells have low baseline levels of Ci155. In control experiments, levels of Ptc and Ci155 were unaffected in $i h o g^{D C 1 / D C 1}$ mutants (not shown), in $b o i^{C 1 /-}$ hemizygous cells (GFP-positive in Figure 4C, D) and in ihog ${ }^{D C 1 / D C 1}$ clones in $\mathrm{boi}^{\mathrm{Cl} /+}$ heterozygotes (12 of 12 clones; GFP-negative in Figure 4A, B).

In contrast, cells lacking both ihog and boi in anterior clones situated near the compartment boundary did not express Ptc and did not accumulate high levels of Ci155 (12 of 12 clones; Figure 4C-D"'), similar to smo clones [27]. Ci155 normally accumulates to high levels even at low concentrations of $\mathrm{Hh}[28,29]$, and so the failure to elicit this low-threshold response indicates that removal of ihog and boi results in complete loss of Hh pathway activation. Importantly, while cells lacking both ihog and boi lost the ability to respond to Hh, cells immediately adjacent to these clones expressed Ptc and accumulated Ci155 normally (arrowheads in Figure 4D'"), indicating that Ihog and Boi are required cell-autonomously in $\mathrm{Hh}$ responding cells.

\section{Ihog and Boi sequester Hh activity}

In response to Hh, upregulation of Ptc levels in anterior cells near the compartment boundary reduces the anterior range of Hh activity [27]. This finding has been fundamental to the prevailing model that Ptc is a $\mathrm{Hh}$ receptor that can directly bind and sequester $\mathrm{Hh}$ protein. An alternative hypothesis is that Ptc interacts indirectly with $\mathrm{Hh}$, perhaps by tethering another protein that directly binds Hh [27]. Since Ihog and Boi bind directly to Hh in vitro [9], and since Ptc and Ihog have been shown to synergize to increase binding of Hh to cultured cells [9], we wondered whether Ihog and Boi could likewise limit the range of Hh activity within the anterior compartment of the wing disc. Therefore, we studied large anterior clones that spanned the usual Ptc expression domain, and examined Ptc and Ci levels in cells immediately anterior to these clones. In cells that were immediately anterior to control $i h o g^{D C 1 / D C 1}$ clones in $b o i^{C l /+}$ heterozygotes, there was no evidence for $\mathrm{Hh}$ pathway activation. In contrast, high levels of both Ptc and Ci155 were observed in cells immediately anterior to clones lacking Ihog and Boi (Figure 4C-D"'), 


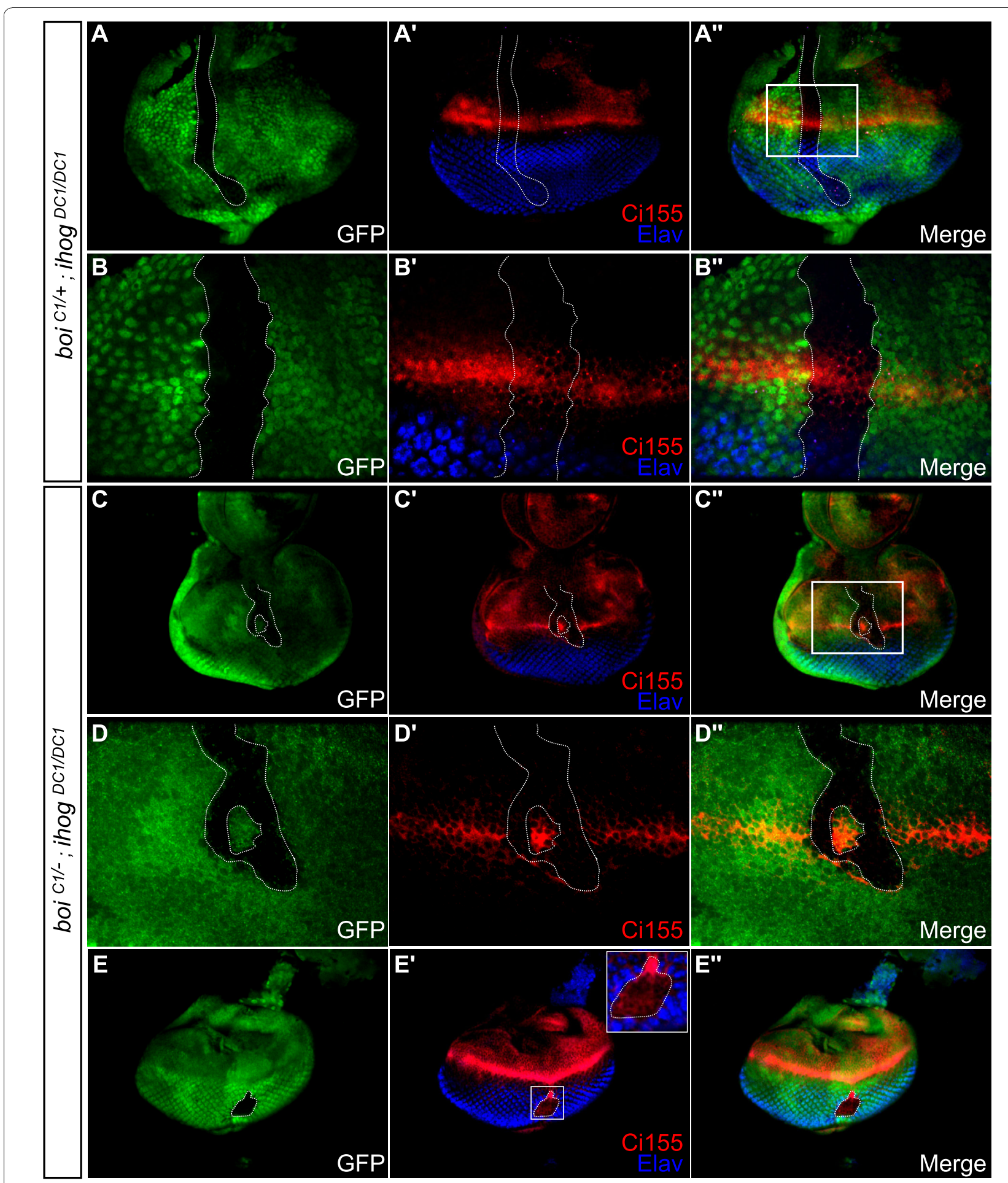

Figure 3 Cells mutant for both ihog and boi do not activate the Hh pathway, disrupting R-cell differentiation in the developing eye disc. $\left(\mathbf{A}-\mathbf{B}^{\prime \prime}\right)$ Control in which an ihog ${ }^{D C 1 / D C 1}$ clone (green fluorescent protein (GFP)-negative cells marked by dotted line) was generated in an eye disc of a boi ${ }^{1 / 1+}$ heterozygote. (A-A") Low magnification view of entire disc. (B-B") High magnification view of boxed area in ( $A^{\prime \prime}$ ). Control clones show normal accumulation of cytoplasmic Ci155 (red) near the MF, and normal expression of Elav (blue) among differentiating R-cells posterior to the MF. (C-E") An ihog ${ }^{D C 1 / D C 1}$ clone (dotted line) in a bo ${ }^{(1 /-}$ mutant. (C-C') Low magnification view. (D-D") Higher magnification view of boxed area in $\left(\mathrm{C}^{\prime \prime}\right)$. Ci155 expression (red) is undetectable in cells mutant for both ihog and boi (GFP-negative, dotted line). (E-E") In a double mutant clone situated well posterior to the MF, the absence of Elav and the ectopic expression of Ci155 indicate a delay of R-cell differentiation. Anterior is at the top in all panels. 


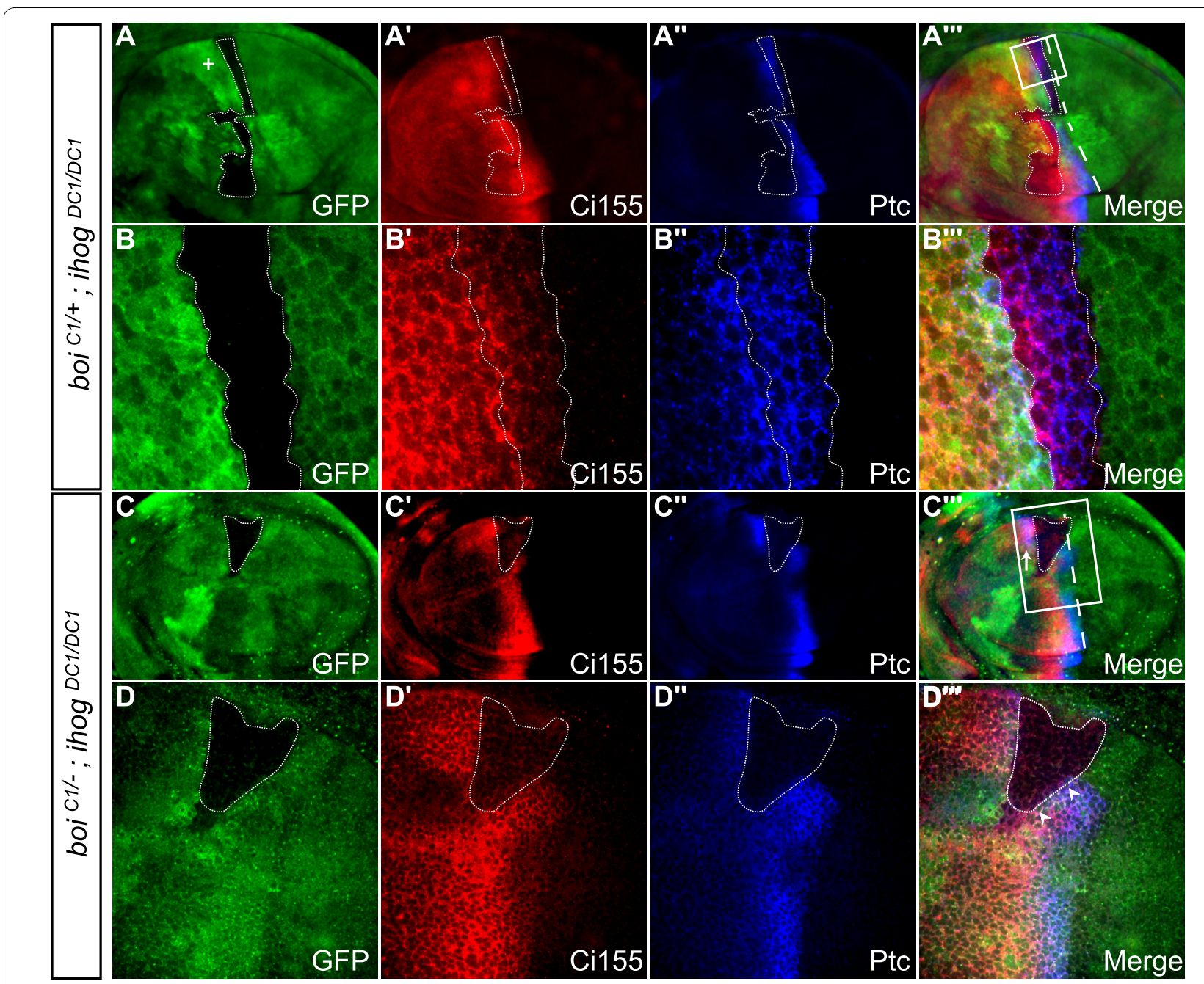

Figure 4 ihog and boi are required for high- and low-threshold responses to Hh pathway activation. All panels show third instar wing imaginal discs with anterior to the left. (A-B'"') Control showing large GFP-negative ihog ${ }^{D C 1 / D C 1}$ clone (outlined with dotted line) in a boi ${ }^{(1 /+}$ heterozygote. The adjacent twin-spot is marked by the high level of GFP staining (the plus sign in (A)). (A-A"') Low magnification view. The white dashed line in ( $\left.A^{\prime \prime \prime}\right)$ marks the normal position of the anterior-posterior boundary. (B- $\left.B^{\prime \prime \prime}\right)$ Higher magnification view of boxed area in ( $\left.A^{\prime \prime \prime}\right)$. Ptc (blue) is a high-threshold $\mathrm{Hh}$ target that is normally activated in anterior cells immediately adjacent to the anterior-posterior compartment boundary, while Ci155 (red) accumulates in cells positioned more anteriorly in response to lower levels of Hh signaling. In this large anterior control clone, there is normal expression of Ptc and Ci155 and no segregation into posterior territory. (C-D'"') An ihog ${ }^{D C 1 / D C 1}$ clone (dotted line) in a boi ${ }^{C 1 /-}$ mutant. $\left(C-C^{\prime \prime \prime}\right)$ Low magnification view. White dashed line in $\left(\mathrm{C}^{\prime \prime}\right)$ marks the normal position of the anterior-posterior boundary. (D$\left.\mathrm{D}^{\prime \prime \prime}\right)$ Higher magnification view of boxed area in $\left(\mathrm{C}^{\prime \prime \prime}\right)$. Clones lacking both ihog and boi were unable to express Ptc or accumulate high levels of Ci155 (GFP-negative, dotted line). High levels of Ptc and Ci155 in cells immediately adjacent to clones (arrowheads in (D"')) indicate that Ihog and Boi are required cell-autonomously in $\mathrm{Hh}$ responding cells, and expression of these markers immediately anterior to the clone (arrow in $\left(C^{\prime \prime \prime}\right)$ ) indicates that loss of Ihog and Boi fails to sequester Hh activity in the clone.

indicating that the loss of both Ihog and Boi fails to restrict the movement of $\mathrm{Hh}$ through the clone.

\section{Ihog and Boi act upstream of Smo}

Activation of the Hh signaling pathway leads to increased accumulation of Smo protein at the surface of cells near the compartment boundary of the wing disc [30]. This accumulation of Smo at the cell surface is required for its signaling activity, and therefore marks Smo activation by Hh [30-33]. Thus, to test whether Ihog and Boi could function upstream of Smo, we examined Smo accumulation in ihog; boi mutant clones. While control clones showed normal Smo accumulation (eight of eight clones; Figure 5A-B"), cells within ihog;boi mutant clones had Smo protein levels that were markedly reduced (seven of seven clones; Figure 5C-D”). Thus, Ihog and Boi are required for the $\mathrm{Hh}$-dependent stabilization of Smo, and these results provide evidence that Ihog and Boi act upstream of Smo in the Hh signaling pathway. 


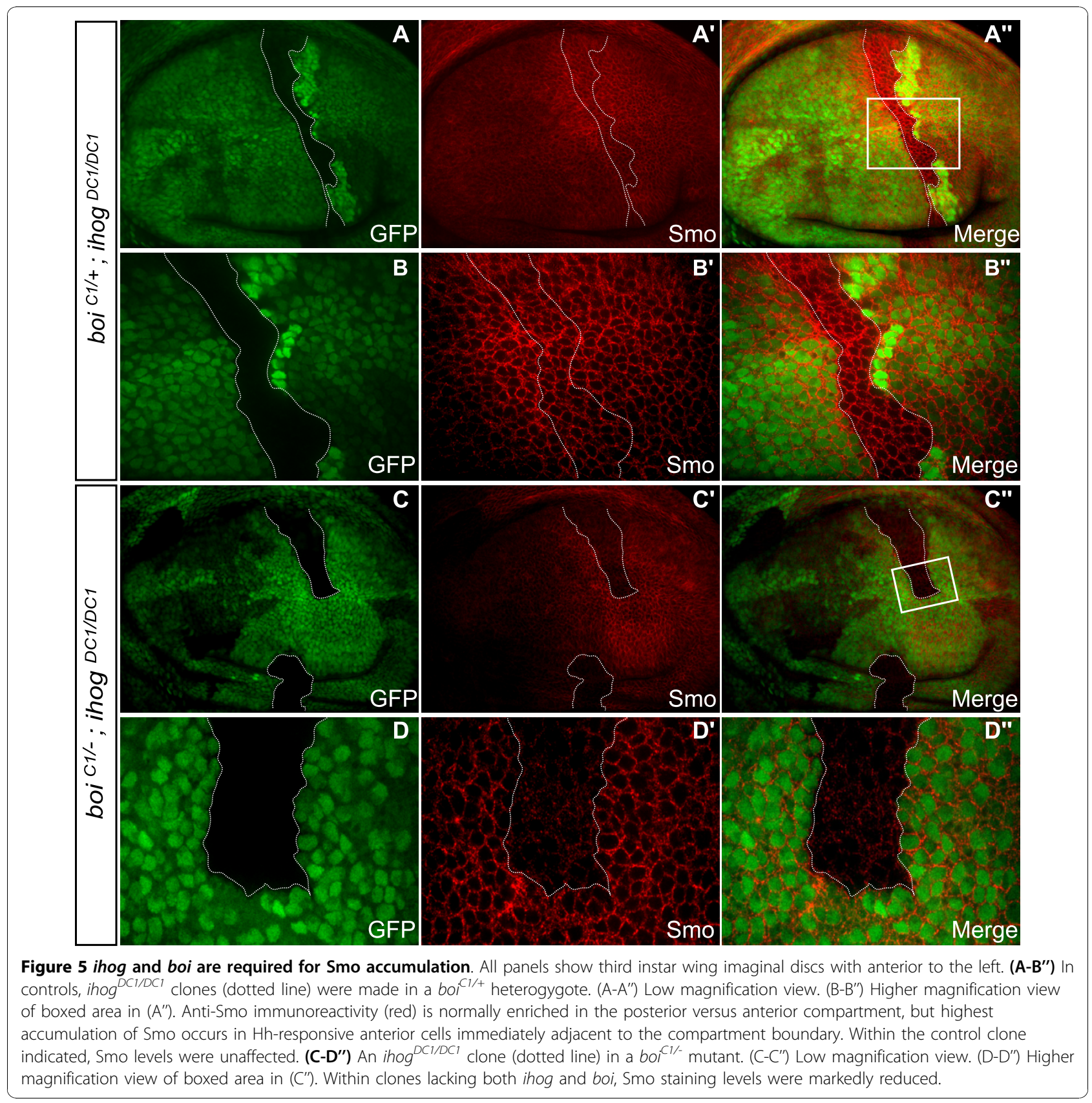

\section{Ihog and Boi are required for compartment-specific cell affinity}

Cells of the wing imaginal disc normally do not cross the boundary between the anterior and posterior compartments, and implementation of this boundary is thought to involve mechanisms that control compartment-specific cell affinity and adhesion [34]. Clonal analysis has demonstrated that $\mathrm{Hh}$ signaling is required to maintain cell affinities in the anterior compartment. For example, if anterior cells that are adjacent to the boundary are mutant for smo or $c i$ [35-37], they sort out from other anterior cells and segregate into posterior territory. To determine if Ihog and Boi are involved in maintaining compartment-specific cell affinities, we examined the segregation behavior of clones near the anterior-posterior compartment boundary. To do this, clones of anterior origin were unambiguously identified if they expressed baseline levels of $\mathrm{Ci}$, and if an adjacent wildtype sister clone, the twin-spot, was situated in the anterior compartment since, by definition, the mutant clone and twin-spot must arise from the same compartment. In controls (ihog ${ }^{D C 1 / D C 1}$ clones in boi ${ }^{C 1 /+}$ heterozygotes), 
anterior-derived clones exclusively occupied anterior territory and defined a straight border with posterior cells in the normal position of the boundary (14 of 14 clones; Figure 4A-B"'). In contrast, double mutant clones (ihog ${ }^{D C 1 / D C 1}$ clones in boi ${ }^{C 1 /-}$ hemizygotes) often straddled the boundary and formed tight borders with both anterior and posterior cells ( 8 of 16 clones; Figure $6)$. This modified segregation behavior indicates that anterior cells lacking both Ihog and Boi sort out from the anterior compartment into posterior territory. These clones do not readily integrate into posterior territory because they do not possess affinity for posterior cells conferred by expression of Engrailed [35]. Consistent with the lack of a known role for Hh signaling in the posterior compartment, double mutant posterior clones respected the compartment boundary and did not sort into anterior territory (11 of 11 clones; Figure 6A'). Together, these results indicate that, like $\mathrm{Smo}$ or $\mathrm{Ci}$, Ihog and Boi are required to maintain cell affinities in the anterior compartment.

\section{Discussion}

\section{Ihog and Boi are essential components of the $\mathrm{Hh}$} pathway

Using genetic approaches in Drosophila, we show that $i h o g$ and boi act redundantly and are required for viability. Mutation of ihog and boi in the developing eye disc prevents Hh signaling and causes severe disruption of photoreceptor differentiation. Similarly, mutation of ihog and boi in the developing wing disc completely abrogates $\mathrm{Hh}$ signaling in a cell-autonomous manner. All these phenotypic effects are identical to mutations of the essential Hh signaling mediator smo and thus indicate that the transmembrane proteins Ihog and Boi are absolutely required for the Hh signaling pathway. We surmise that the essential role for $i h o g$ and boi in Hh signaling was not discovered previously because they are redundant with one another, and therefore refractory to conventional forward genetic screens in Drosophila.

A previous study of the lethal mutation ihog ${ }^{K G}$ reported defects that mimicked those caused by mutations of the Hh signaling pathway [9]. That $i \operatorname{hog}^{K G}$ disrupts gene(s) in addition to ihog is indicated by the fact that zygotic mutation of $i h g^{K G}$ alone is lethal, while the null allele $i h o g^{D C 1}$ is not. $i h o g^{K G}$ was reported to disrupt Ptc expression in the wing disc, and the patterning of wing veins [9], but we did not observe these effects with ihog ${ }^{D C 1}$ null mutations (Figure 4A", B"). In addition, germline clones of $i h g^{K G}$ were found to disrupt patterning of the embryonic cuticle [9]. Therefore, it was unexpected that our maternal/zygotic ihog ${ }^{D C 1}$ null mutants survived at least to pupal stages, and that there were no overt Hh-like phenotypes in the occasional flies that managed to escape the lethal phase and reach adulthood. Indeed, such flies looked remarkably normal. Perhaps the phenotypes observed in $i h o g^{K G}$ are rare, or due to the disrupted function of the neighboring gene CG10158 or another gene in addition to ihog.

In Drosophila, genetic experiments have suggested that Ptc is the Hh receptor [38] and subsequent work has shown Ptc co-localization with $\mathrm{Hh}$ in S2 cells [39]. This has led to the model that Ptc binds Hh, though

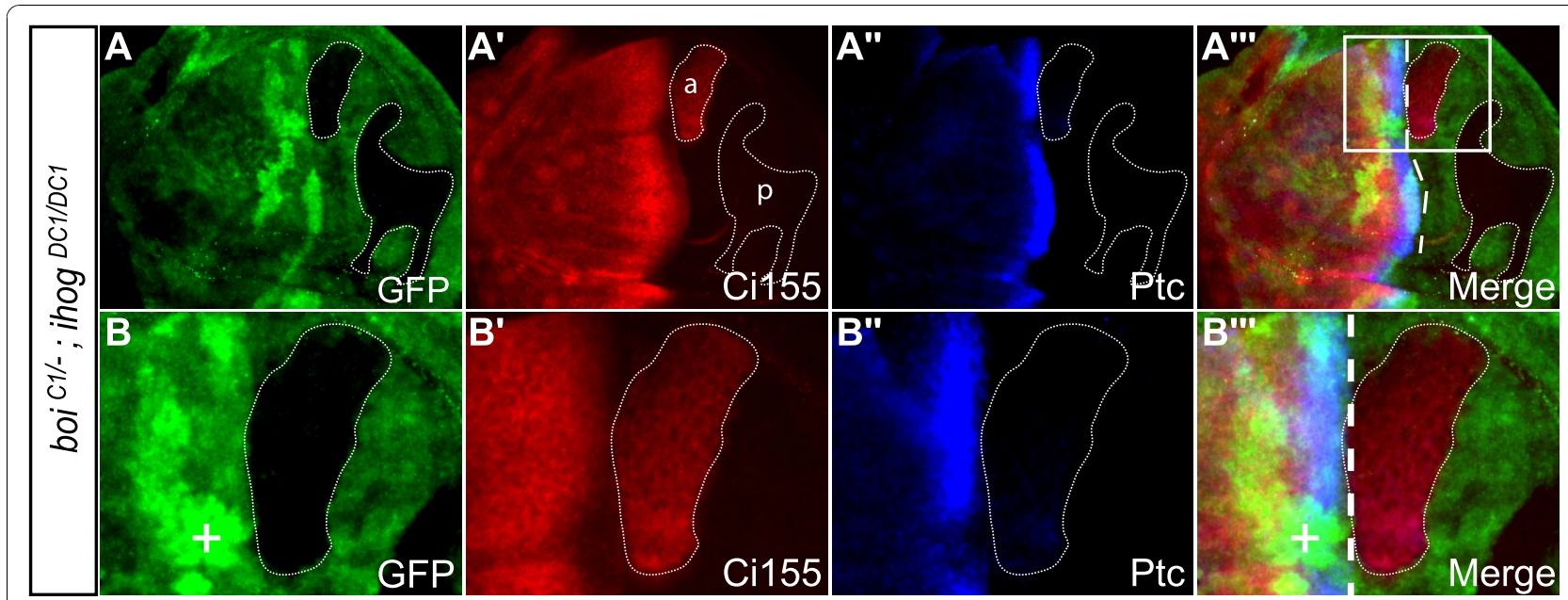

Figure 6 ihog and boi are required to maintain the affinity boundary between anterior and posterior compartments. All panels show third instar wing imaginal discs with anterior to the left. (A-B'"') ihog ${ }^{D C 1 / D C 1}$ clones (dotted line) in a boi ${ }^{(1 /-}$ mutant. (A-A"') Low magnification view. A clone of anterior origin (labelled $a$ in $\left(A^{\prime}\right)$ ) is identified by the expression of basal levels of Ci155. A clone of posterior origin (labelled $p$ in $\left(A^{\prime}\right)$ ) does not express Ci155. (B-B $\left.B^{\prime \prime \prime}\right)$ Higher magnification view of boxed area in ( $\left.A^{\prime \prime \prime}\right)$. The anterior-derived double mutant clone (dotted line) is found in posterior territory. The adjacent twin-spot is marked by the high level of GFP staining (labelled with the plus sign in (B, $\left.B^{\prime \prime \prime}\right)$ ). The white dashed line in $\left(A^{\prime \prime \prime}, B^{\prime \prime \prime}\right)$ marks the normal position of the anterior-posterior boundary. 
experiments have yet to demonstrate direct physical contact. In vertebrates, expression of the Ptc ortholog Ptc1 in cells promoted Sonic hedgehog (Shh) binding, suggesting that Ptc1 is a receptor for Shh $[40,41]$. However, as noted by the authors in those studies, Shh could use additional receptors and Ptc could affect their ability to bind to Shh. Addressing the important question of whether Ptc/Ptc1 bind directly to $\mathrm{Hh} / \mathrm{Sh}$ is likely to require purified proteins in cell-free systems, a challenge for transmembrane proteins with complex topologies like Ptc. Interestingly, Ihog and Boi have been shown to bind directly to $\mathrm{Hh}[9,10]$. Here we found that clones mutant for both ihog and boi phenocopied the effects of smo mutations for Hh signaling. Thus, our data demonstrate that Ihog and Boi are essential components of the Hh pathway. Coupled with our finding that Ihog and Boi act upstream of Smo and sequester Hh activity, this raises the possibility that Ihog and Boi are Hh-binding components of the Hh receptor complex. While preparing this manuscript, another research group came to a similar conclusion [42]. Using biochemical experiments, they further suggest that Ihog/Boi, together with Ptc and Hh, form a complex and that the presence of Ihog/ Boi in this complex is essential to allow Ptc to bind to Hh. However, since purified proteins were not used in these experiments, it remains to be determined whether the interaction between $\mathrm{Hh}$ and Ptc is direct. Alternatively, Ptc could affect the ability of an additional protein (perhaps Ihog or Boi) to recruit Hh. Thus, the question as to whether Ptc binds directly to $\mathrm{Hh}$, in the absence or the presence of Ihog/Boi, remains to be elucidated. Additional experiments will be required to understand the exact contributions of Ihog, Boi and Ptc to the reception and transduction of the Hh signal. Nonetheless, our experiments and those of Zheng and colleagues identify Ihog and Boi as essential components of a Hh receptor complex.

In addition to Ihog and Boi, other membrane-tethered Hh-binding proteins, such as the glypican family members, have been identified [8,43-45]. Although it is possible that other developing tissues may use different $\mathrm{Hh}$ binding molecules as sensors for $\mathrm{Hh}$, our data indicate that Ihog and Boi are critical to elicit Hh signaling and that, at least in developing imaginal tissues, no other molecule can compensate for loss of Ihog and Boi.

\section{Ihog and Boi: transmembrane IgSF proteins with potential to mediate cell affinity}

In addition to the role of Ihog and Boi in wing cell fate specification (Zheng et al. [42] and this study), we show for the first time that Ihog and Boi are required for maintenance of the antero-posterior boundary of the wing disc. Formation of this boundary is thought to involve cell-surface recognition molecules responsible for affinity among anterior cells. Since $c i$ mutant clones lose affinity for the anterior compartment [37], it is likely that such adhesion molecules are transcriptionally regulated by the Hh pathway. Despite broad screening efforts to identify these molecules [46], they remain unidentified. While the loss of cell affinity in boi;ihog double mutant clones is likely a consequence of loss of $\mathrm{Hh}$ signaling, it is an intriguing possibility that Ihog and/or Boi could also be $\mathrm{Ci}$-regulated recognition molecules promoting the differential compartment-specific cell affinity. Consistent with this hypothesis, the vertebrate orthologs of Ihog and Boi, called Cdon (Cell adhesion molecule-related/down-regulated by oncogenes) and Boc (Brother of Cdon), can interact with each other and form higher-order cell-surface complexes with the wellcharacterized adhesion molecules $\mathrm{N}$ - and $\mathrm{M}$-cadherin $[7,47]$. These complexes mediate cell-cell interactions between muscle precursor cells and are enriched at sites of contact between myoblasts. Similar to Cdon and Boc, Ihog and Boi could mediate cell-cell interactions, and might play a direct role in compartment-specific cell affinity.

\section{Ihog and Boi and their vertebrate orthologs in nervous system development}

Although Cdon and Boc have also been shown to play a role in Hh signaling in vertebrates [9,48-50], their absolute requirement for Hh signaling has not been demonstrated, and mouse embryos mutant for both cdon and boc do not display a smo-like phenotype (our unpublished data). Additionally, $\mathrm{Hh}$ binds to Ihog/Boi in a manner that is different from Shh binding to Cdon and Boc $[10,51]$, suggesting that a direct extrapolation of our work in flies to Cdon and Boc could be subject to added complexities.

Nevertheless, there are enough interesting parallels between Ihog and Boi and their vertebrate orthologs in the developing nervous system to warrant further investigation. We have shown here that Ihog and Boi are essential for the differentiation of R-cells in the developing fly visual system. Interestingly, overexpression studies in chick have shown that Boc and Cdon promote Shhinduced differentiation in the neural tube and that Cdon is required for Shh-dependent cell fate specification in the neural tube $[48,50]$. Furthermore, Boc has been shown to be essential for axon guidance through the activation of a non-canonical, transcription-independent Shh signaling pathway mediated by the activity of Src-family kinases $[49,52,53]$. It will be interesting to determine whether Ihog and Boi also function in axon guidance and whether they may contribute to non-canonical Hh signaling in Drosophila. 


\section{Conclusions}

We conclude that the transmembrane proteins Ihog and Boi are essential components of the Hh signaling pathway. Ihog and Boi act upstream of Smo and sequester Hh activity, raising the possibility that Ihog and Boi are Hhbinding components of the Hh receptor complex. These findings advance our understanding of the molecular signaling mechanism underlying the function of $\mathrm{Hh}$.

\section{Materials and methods}

\section{Fly stocks}

ihog ${ }^{D C 1}$ was generated by Flippase (FLP)-mediated recombination between Flippase recognition target (FRT) sites in $\mathrm{pBac}\{\mathrm{RB}\} C \mathrm{C} 10158^{\mathrm{e} 02576}$ and $\mathrm{pBac}\{\mathrm{RB}\}$ $\mathrm{iHog}^{\mathrm{e}}{ }^{0142}[54,55]$. After out-crossing to $w^{1118}$, the resulting chimeric pBac element was excised, and the predicted deletion of 3,479 bp was confirmed by DNA sequencing and RT-PCR (Figure 2D). A deficiency stock that uncovers the ihog locus (Df(2L)Exel7029) was also used, and is designated $i h g^{D f}$ herein.

$b o i^{C 1}$ was identified in a screen for mutations that suppress ectopic wing veins caused by $a p^{G A L 4}$-driven expression of $\mathrm{P}\{\mathrm{EP}\}$ EP1447, a UAS-based P-element situated upstream of the boi gene (Figure S1A). Briefly, starved EP1447 male flies were exposed to $25 \mathrm{mM}$ ethylmethanesulfonate (EMS) overnight, then crossed to $a p^{G A L 4}$ virgin females. $b o i^{C 1}$ was identified among approximately 15,000 adult progeny screened for suppression of ectopic wing veins. $b o i^{C l}$ proved to be a viable mutation, and so PCR and DNA sequencing were used to compare the boi coding region in $b o i^{C 1}$ homozygotes with the parental line EP1447. An induced G-to-A transition was found in $b i^{C 1}$, resulting in a nonsense mutation at Trp626.

To create UAS-ihog::myc, the entire coding sequence of ihog (minus stop codon) was PCR-amplified from an ihog cDNA (GH03927), and cloned into pCR2.1-TOPO (Invitrogen, Carlsbad, CA, USA). This fragment was excised and cloned into p5MT2Stp (BamHI/SalI) to add five copies of the myc epitope to the carboxyl terminus. UAS- ihog::myc was generated by KpnI/NotI excision and cloning into pUASt. Transgenic flies were generated in a w- background by standard microinjection procedures (BestGene Inc., San Diego, CA, USA).

\section{Mosaic analysis}

Mosaic adult eyes were obtained by crossing $b_{o i}{ }^{C l / C l}$; ihog ${ }^{D C 1}, F R T 40 A /+$ females to FRT40A, l(2)CL-L ${ }^{1}$; eyFLP males [14]. Wing and eye disc clones marked by the absence of GFP were generated by crossing $\mathrm{boi}^{\mathrm{Cl} / \mathrm{Cl} \text {; }}$ ihog ${ }^{D C 1}$, FRT40A/+ females to Ubi-GFP, FRT40A; hsFLP males. In this way, ihog ${ }^{D C 1 / D C 1}$ clones would be generated in $b o i^{C l /+}$ heterozygotes (female progeny) or $\mathrm{boi}^{\mathrm{Cl} / \mathrm{-}}$ hemizygotes (male progeny). Embryos were collected for 16 hours, raised for 24 hours $\left(25^{\circ} \mathrm{C}\right)$, then the larvae were heat shocked at $38^{\circ} \mathrm{C}$ for 1 hour and further raised $\left(25^{\circ} \mathrm{C}\right)$ through $\mathrm{L} 3$.

\section{Immunohistochemistry}

Wandering L3 larvae were dissected and fixed according to standard procedures, just prior to pupation. Monoclonal antibodies obtained from the Developmental Studies Hybridoma Bank included: mouse anti-Ptc (dilution 1:50), mouse anti-Smo (1:50) and mouse anti-Elav $(1: 2,000)$. Other antibodies used were rabbit anti-GFP (1:1,000; Molecular Probes, Eugene, OR, USA) and rat anti-Ci155 (1:2,000) [19]. Secondary antibodies were: Alexa Fluor 488 conjugated goat anti-rabbit (1:300); Alexa Fluor 647 conjugated goat anti-mouse (1:300); and Alexa Fluor 588 conjugated goat anti-rat (1:300), all from Molecular Probes.

\section{In situ hybridization}

A digoxigenin (Dig)-labeling kit (Roche, Indianapolis, IN, USA) was used to synthesize cRNA probes from a BglIIdigested ihog cDNA (GH03927) and an EcoRI-digested boi cDNA (SD07678), using T7 and Sp6 RNA polymerases, respectively. Prepared L3 larvae were hybridized with probes overnight at $55^{\circ} \mathrm{C}$ using standard procedures, and visualized using anti-Dig-AP (1:1,000; Roche).

\section{RT-PCR}

RT-PCR was performed on total RNA isolated from adult flies. The ihog primer set was designed to amplify a band of $411 \mathrm{bp}$ from the UAS-ihog::myc transgene, but not ihog ${ }^{D C 1 / D C 1}$ mutants (5'-CCCTGAGCAAGTGTGGAGAT-3'; 5'-CTCTAGGCGAGTACCGATGC-3'). An Actin5C fragment of 586 bp was co-amplified as a control (5'-GAGCGCGGTTACTCTTTCAC-3'; 5'-ATCCCGATCCTGATCCTCTT-3').

\section{Additional material}

Additional file 1: Ectopic wing veins caused by overexpression of Boi. (A) Wing from a EP1447/+; a $p^{G A L 4} /+$ fly, showing an ectopic vein (arrow and magnified boxed area) located between veins $L 3$ and $L 4$. Additional wing defects were also observed, though these were variable (arrowheads). (B) Wing from a fly of the genotype EP1447, boi ${ }^{\mathrm{Cl}} /+$; $a p^{G A L 4} /+$, showing complete suppression of the ectopic vein defect.

\section{Abbreviations}

BOC: Brother of Cdon; BOI: Brother of Ihog; BP: base pair; CDON: Cell adhesion molecule-related/down-regulated by oncogenes; Cl: Cubitus interruptus; DIG: digoxigenin; FN3: fibronectin type III; GFP: green fluorescent protein; HH: Hedgehog; IG: immunoglobulin-like; IGSF: immunoglobulin superfamily; IHOG: Interference hedgehog; L3: third instar; MF:

morphogenetic furrow; PTC: Patched; RT-PCR: reverse transcriptase PCR; SHH: Sonic hedgehog; SMO: Smoothened. 


\section{Acknowledgements}

We are grateful to Keith Murai for critical reading of the manuscript. We thank Steves Morin and Yimiao Ou for technical assistance; Yong Rao, David Hipfner, Scott Cameron and Laura Nilson for advice; and Tom Kornberg, Phil Beachy, Jin Jiang, Isabel Guerrero and Gary Struhl for reagents. Fly stocks were obtained from the Bloomington Stock Center and the Exelixis Collection at Harvard. This work was supported by the Canadian Institutes of Health Research (CIHR), the Natural Sciences and Engineering Research Council of Canada (NSERC), the Peter Lougheed Medical Research Foundation, the Fonds de Recherche en Santé du Québec (FRSQ), and the Canada Foundation for Innovation (CFI).

\section{Author details}

'Molecular Biology of Neural Development, Institut de Recherches Cliniques de Montréal (IRCM), Montreal, QC, H2W 1R7, Canada. ${ }^{2}$ Centre for Research in Neuroscience and the McGill University Health Centre Research Institute, 1650 Cedar Ave, Montreal, QC, H3G 1A4, Canada. ${ }^{3}$ Division of Experimental Medicine, McGill University, Montreal, QC, Canada. ${ }^{4}$ Department of Neurology and Neurosurgery, McGill University, Montreal, QC, Canada. ${ }^{5}$ Department of Biology, McGill University, Montreal, QC, Canada. ${ }^{6}$ Program in Neuroengineering, McGill University, Montreal, QC, Canada. ${ }^{7}$ Department of Medicine, University of Montreal, Montreal, QC, Canada. ${ }^{8}$ Department of Anatomy and Cell Biology, McGill University, Montreal, QC, Canada.

\section{Authors' contributions}

DC performed the experiments, participated in their design, analysis and interpretation, and drafted the manuscript. KC participated in the genetic screen, AL constructed the UAS-ihog transgene, and both helped in data analysis and interpretation. DJVM and FC conceived of the study, and participated in its design and coordination and drafted the manuscript. All authors read and approved the final manuscript.

\section{Competing interests}

The authors declare that they have no competing interests.

Received: 17 July 2010 Accepted: 2 November 2010 Published: 2 November 2010

\section{References}

1. Varjosalo M, Li SP, Taipale J: Divergence of hedgehog signal transduction mechanism between Drosophila and mammals. Dev Cell 2006, 10:177-186.

2. Lum L, Beachy PA: The Hedgehog response network: sensors, switches, and routers. Science 2004, 304:1755-1759.

3. Jiang J, Hui CC: Hedgehog signaling in development and cancer. Dev Cell 2008, 15:801-812.

4. Dessaud E, McMahon AP, Briscoe J: Pattern formation in the vertebrate neural tube: a sonic hedgehog morphogen-regulated transcriptional network. Development 2008, 135:2489-2503.

5. Charron F, Tessier-Lavigne M: Novel brain wiring functions for classical morphogens: a role as graded positional cues in axon guidance. Development 2005, 132:2251-2262.

6. Roignant JY, Treisman JE: Pattern formation in the Drosophila eye disc. Int J Dev Biol 2009, 53:795-804

7. Kang JS, Mulieri PJ, Hu Y, Taliana L, Krauss RS: BOC, an Ig superfamily member, associates with $\mathrm{CDO}$ to positively regulate myogenic differentiation. EMBO J 2002, 21:114-124.

8. Lum L, Yao S, Mozer B, Rovescalli A, Von Kessler D, Nirenberg M, Beachy PA: Identification of Hedgehog pathway components by RNAi in Drosophila cultured cells. Science 2003, 299:2039-2045.

9. Yao S, Lum L, Beachy P: The inog cell-surface proteins bind Hedgehog and mediate pathway activation. Cell 2006, 125:343-357.

10. McLellan JS, Yao S, Zheng X, Geisbrecht BV, Ghirlando R, Beachy PA, Leahy DJ: Structure of a heparin-dependent complex of Hedgehog and Ihog. Proc Natl Acad Sci USA 2006, 103:17208-17213.

11. Wolff T, Ready DF: Pattern formation in the Drosophila retina. In The Development of Drosophila melanogaster. Volume 2. Edited by: Bate M, Martinez-Arias A. Cold Spring Harbor, NY: Cold Spring Harbor Laboratory Press; 1993:1277-1325.

12. Baker $\mathrm{N}$, Bhattacharya $\mathrm{A}$, Firth $\mathrm{L}$ : Regulation of Hh signal transduction as Drosophila eye differentiation progresses. Dev Biol 2009, 335:356-366.
13. Strutt $D$, Mlodzik M: Hedgehog is an indirect regulator of morphogenetic furrow progression in the Drosophila eye disc. Development 1997, 124:3233-3240.

14. Stowers RS, Schwarz TL: A genetic method for generating Drosophila eyes composed exclusively of mitotic clones of a single genotype. Genetics 1999, 152:1631-1639.

15. Dominguez M: Dual role for Hedgehog in the regulation of the proneural gene atonal during ommatidia development. Development 1999, 126:2345-2353.

16. Heberlein U, Wolff T, Rubin GM: The TGF beta homolog dpp and the segment polarity gene hedgehog are required for propagation of a morphogenetic wave in the Drosophila retina. Cell 1993, 75:913-926.

17. Ma C, Zhou Y, Beachy PA, Moses K: The segment polarity gene hedgehog is required for progression of the morphogenetic furrow in the developing Drosophila eye. Cell 1993, 75:927-938.

18. Kalderon D: The mechanism of hedgehog signal transduction. Biochem Soc Trans 2005, 33:1509-1512.

19. Aza-Blanc P, Ramirez-Weber FA, Laget MP, Schwartz C, Kornberg TB: Proteolysis that is inhibited by hedgehog targets Cubitus interruptus protein to the nucleus and converts it to a repressor. Cell 1997, 89:1043-1053

20. Motzny CK, Holmgren R: The Drosophila cubitus interruptus protein and its role in the wingless and hedgehog signal transduction pathways. Mech Dev 1995, 52:137-150.

21. Strutt DI, Mlodzik M: The regulation of hedgehog and decapentaplegic during Drosophila eye imaginal disc development. Mech Dev 1996, 58:39-50.

22. Lawrence PA, Morata G: Compartments in the wing of Drosophila: a study of the engrailed gene. Dev Biol 1976, 50:321-337.

23. Tabata T, Schwartz C, Gustavson E, Ali Z, Kornberg TB: Creating a Drosophila wing de novo, the role of engrailed, and the compartment border hypothesis. Development 1995, 121:3359-3369.

24. Zecca M, Basler K, Struhl G: Sequential organizing activities of engrailed, hedgehog and decapentaplegic in the Drosophila wing. Development 1995, 121:2265-2278

25. Torroja C, Gorfinkiel N, Guerrero I: Mechanisms of Hedgehog gradient formation and interpretation. J Neurobiol 2005, 64:334-356.

26. Strigini M, Cohen SM: A Hedgehog activity gradient contributes to AP axial patterning of the Drosophila wing. Development 1997, 124:4697-4705.

27. Chen $Y$, Struhl G: Dual roles for patched in sequestering and transducing Hedgehog. Cell 1996, 87:553-563.

28. Mullor JL, Calleja M, Capdevila J, Guerrero I: Hedgehog activity, independent of decapentaplegic, participates in wing disc patterning. Development 1997, 124:1227-1237.

29. Aza-Blanc P, Kornberg TB: Ci: a complex transducer of the hedgehog signal. Trends Genet 1999, 15:458-462.

30. Denef N, Neubuser D, Perez L, Cohen SM: Hedgehog induces opposite changes in turnover and subcellular localization of patched and smoothened. Cell 2000, 102:521-531.

31. Zhu AJ, Zheng L, Suyama K, Scott MP: Altered localization of Drosophila Smoothened protein activates Hedgehog signal transduction. Genes Dev 2003, 17:1240-1252.

32. Nakano Y, Nystedt S, Shivdasani AA, Strutt $H$, Thomas C, Ingham PW: Functional domains and sub-cellular distribution of the Hedgehog transducing protein Smoothened in Drosophila. Mech Dev 2004, 121:507-518.

33. Jia J, Tong C, Wang B, Luo L, Jiang J: Hedgehog signalling activity of Smoothened requires phosphorylation by protein kinase $A$ and casein kinase I. Nature 2004, 432:1045-1050.

34. Dahmann C, Basler K: Compartment boundaries: at the edge of development. Trends Genet 1999, 15:320-326.

35. Blair SS, Ralston A: Smoothened-mediated Hedgehog signalling is required for the maintenance of the anterior-posterior lineage restriction in the developing wing of Drosophila. Development 1997, 124:4053-4063.

36. Rodriguez I, Basler K: Control of compartmental affinity boundaries by hedgehog. Nature 1997, 389:614-618.

37. Dahmann C, Basler K: Opposing transcriptional outputs of Hedgehog signaling and engrailed control compartmental cell sorting at the Drosophila A/P boundary. Cell 2000, 100:411-422. 
38. Ingham PW, Taylor AM, Nakano Y: Role of the Drosophila patched gene in positional signalling. Nature 1991, 353:184-187.

39. Lu X, Liu S, Kornberg TB: The C-terminal tail of the Hedgehog receptor Patched regulates both localization and turnover. Genes Dev 2006, 20:2539-2551

40. Stone DM, Hynes M, Armanini M, Swanson TA, Gu Q, Johnson RL, Scott MP, Pennica D, Goddard A, Phillips H, Noll M, Hooper JE, de Sauvage F, Rosenthal A: The tumour-suppressor gene patched encodes a candidate receptor for Sonic hedgehog. Nature 1996, 384:129-134.

41. Marigo V, Davey RA, Zuo Y, Cunningham JM, Tabin CJ: Biochemical evidence that patched is the Hedgehog receptor. Nature 1996, 384:176-179.

42. Zheng X, Mann RK, Sever N, Beachy PA: Genetic and biochemical definition of the Hedgehog receptor. Genes Dev 2010, 24:57-71.

43. Ayers KL, Gallet A, Staccini-Lavenant L, Therond PP: The long-range activity of Hedgehog is regulated in the apical extracellular space by the glypican Dally and the hydrolase Notum. Dev Cell 2010, 18:605-620.

44. Gallet A, Staccini-Lavenant L, Therond PP: Cellular trafficking of the glypican Dally-like is required for full-strength Hedgehog signaling and wingless transcytosis. Dev Cell 2008, 14:712-725.

45. Williams EH, Pappano WN, Saunders AM, Kim MS, Leahy DJ, Beachy PA: Dally-like core protein and its mammalian homologues mediate stimulatory and inhibitory effects on Hedgehog signal response. Proc Natl Acad Sci USA 2010, 107:5869-5874.

46. Vegh M, Basler K: A genetic screen for hedgehog targets involved in the maintenance of the Drosophila anteroposterior compartment boundary. Genetics 2003, 163:1427-1438.

47. Kang JS, Feinleib JL, Knox S, Ketteringham MA, Krauss RS: Promyogenic members of the Ig and cadherin families associate to positively regulate differentiation. Proc Natl Acad Sci USA 2003, 100:3989-3994.

48. Tenzen T, Allen BL, Cole F, Kang JS, Krauss RS, McMahon AP: The cell surface membrane proteins $\mathrm{Cdo}$ and Boc are components and targets of the Hedgehog signaling pathway and feedback network in mice. Dev Cell 2006, 10:647-656.

49. Okada A, Charron F, Morin S, Shin DS, Wong K, Fabre PJ, Tessier-Lavigne M, McConnell SK: Boc is a receptor for sonic hedgehog in the guidance of commissural axons. Nature 2006, 444:369-373.

50. Zhang W, Kang JS, Cole F, Yi MJ, Krauss RS: Cdo functions at multiple points in the Sonic Hedgehog pathway, and Cdo-deficient mice accurately model human holoprosencephaly. Dev Cell 2006, 10:657-665.

51. McLellan JS, Zheng X, Hauk G, Ghirlando R, Beachy PA, Leahy DJ: The mode of Hedgehog binding to Ihog homologues is not conserved across different phyla. Nature 2008, 455:979-983.

52. Fabre PJ, Shimogori T, Charron F: Segregation of ipsilateral retinal ganglion cell axons at the optic chiasm requires the Shh receptor Boc. J Neurosci 2010, 30:266-275.

53. Yam PT, Langlois SD, Morin S, Charron F: Sonic hedgehog guides axons through a noncanonical, Src-family-kinase-dependent signaling pathway. Neuron 2009, 62:349-362.

54. Parks AL, Cook KR, Belvin M, Dompe NA, Fawcett R, Huppert K, Tan LR, Winter CG, Bogart KP, Deal JE, Deal-Herr ME, Grant D, Marcinko M, Miyazaki WY, Robertson S, Shaw KJ, Tabios M, Vysotskaia V, Zhao L, Andrade RS, Edgar KA, Howie E, Killpack K, Milash B, Norton A, Thao D, Whittaker K, Winner MA, Friedman L, Margolis J, et al: Systematic generation of high-resolution deletion coverage of the Drosophila melanogaster genome. Nat Genet 2004, 36:288-292.

55. Thibault ST, Singer MA, Miyazaki WY, Milash B, Dompe NA, Singh CM, Buchholz R, Demsky M, Fawcett R, Francis-Lang HL, Ryner L, Cheung LM, Chong A, Erickson C, Fisher WW, Greer K, Hartouni SR, Howie E, Jakkula L, Joo D, Killpack K, Laufer A, Mazzotta J, Smith RD, Stevens LM, Stuber C, Tan LR, Ventura R, Woo A, Zakrajsek I, et al: A complementary transposon tool kit for Drosophila melanogaster using P and piggyBac. Nat Genet 2004, 36:283-287.

doi:10.1186/1749-8104-5-28

Cite this article as: Camp et al.: Ihog and Boi are essential for Hedgehog signaling in Drosophila. Neural Development 2010 5:28.

\section{Submit your next manuscript to BioMed Central and take full advantage of:}

- Convenient online submission

- Thorough peer review

- No space constraints or color figure charges

- Immediate publication on acceptance

- Inclusion in PubMed, CAS, Scopus and Google Scholar

- Research which is freely available for redistribution

Submit your manuscript at www.biomedcentral.com/submit 